\title{
The Role of Foreign Direct Investment, Energy and Pollution in Obtaining Sustainable Economic Development
}

\author{
Sandra Jednak ${ }^{1 *}$, Jelena Minović ${ }^{2}$, Dragana Kragulj ${ }^{1}$ \\ ${ }^{1}$ University of Belgrade, Faculty of Organizational Sciences, Serbia \\ ${ }^{2}$ Institute of Economic Sciences, Serbia
}

Received: 5 September 2020

Accepted: 8 March 2021

\begin{abstract}
Developing countries have encountered the issues of economic development and reducing pollution that need to be resolved to achieve sustainable development. However, this topic has not been widely explored. Since obtaining sustainable economic development is a priority, the nexus between foreign direct investment (FDI), trade openness (TO), final energy consumption (FEC), capital (K), income, and pollution (carbon emission) has been investigated in this paper. The research questions deal with the existence of the long-run, short-run and causality relationship between the selected variables. The paper aims to investigate these relations in Serbia during 1995-2018 by applying the autoregressive distributed lag model as the most commonly used and suitable co-integration model. The results present that FDI and TO will increase gross domestic product (GDP), while pollution will decrease it in the long-run. The existence of a short-run causality from FDI and TO to GDP is confirmed. The Granger causality test reveals that FDI has a unidirectional relationship to GDP, carbon emission, TO, and FEC. Furthermore, GDP, carbon emission and FEC have a unidirectional relation to TO. These results indicate that policies should combine FDI promotion and TO, with supervision of FDI effects on carbon emission to obtain sustainable economic development.
\end{abstract}

Keywords: economic development, energy, environment, Serbia

\section{Introduction}

Economic growth and development are primarily directed towards achieving economic benefits and social welfare. However, limited natural resources are used to obtain these goals, and exploitation of limited resources

*e-mail: sandra.jednak@fon.bg.ac.rs can cause changes in the environment. Environmental (air, water and soil) pollution has become a global issue due to rapid industrialisation and urbanisation [1], mining and exploration, and burning fossil fuels [2]. This problem has become a serious issue in developing countries owing to low living standard, and lack of pollution regulations and awareness [3]. As a response to environmental degradation, economies introduce various solutions, including new environmental policies, laws, regulations, and standards. Some of them 
also introduce the concept of efficiently using resources (reduce, reuse and recycle), sustainable products, waste prevention, applying sustainability, and moving toward a sustainable economy.

Fossil fuels are still dominant in the energy mix of developing countries. The consequence of predominant utilisation of fossil fuels is greenhouse emission that influences global warming and climate changes. In order to reduce pollution and negative consequences of energy use at the acquired level of economic development, it is necessary to use energy more efficiently and rely on renewable energy resources. The priority issue is to decide on how to achieve economic growth, reduce energy consumption, and mitigate contamination. That is why the concept of sustainable development was introduced - to ensure sustainability, economic progress, and environmental protection.

For the stated reasons, over the past few years, the emerging issue has been the carbon emission, GDP and energy consumption nexus [4]. Adedoyin and Zakari [5] used the Autoregressive distributed lag model (ARDL) and Granger causality to analyse economic boom, energy consumption, and pollution in the UK covering the period 1985-2017. They discovered a unidirectional causality from energy use to carbon emission. Appiah [6] examined the energy, economic growth and $\mathrm{CO}_{2}$ emission nexus in Ghana for the period 1960-2015 using ARDL and Granger causality test. The study reveals feedback causality between the used energy and pollution. It also confirms that energy consumption and economic growth nexus exists. Naminse and Zhuang [7] investigated the link between economic growth, energy intensity and carbon emission in China. The finding shows that coal consumption increases pollution. It is confirmed that energy consumption and GDP increase pollution in Pakistan [8].

Moreover, in some countries, other economic factors such as trade liberalisation and FDI may play the essential role in obtaining economic growth and reducing energy consumption and $\mathrm{CO}_{2}$ emission [9, $10,11,12]$. Trade liberalisation and FDI can still affect $\mathrm{CO}_{2}$ emission differently depending on whether the foreign capital is invested in pollution-intensive, or non-pollution intensive production [13]. According to traditional growth theory, trade increases economic growth rate. Trade liberalisation policies increase trade openness, and higher trade openness can provide better allocation of resources, access to goods and services, and consequently - output increase [14, 15]. However, the change in $\mathrm{CO}_{2}$ emission depends on the type of goods and resources (dirty or normal goods; renewable or non-renewable resources). That is why exploring this relationship is also crucial for the impact of FDI and trade openness on income and pollution [16, 17]. Analysing the relationship between GDP, financial development, trade openness, energy consumption, and carbon emission in Nigeria (1971-2011) using ARDL and VECM models, Rafindadi [18] detected that economic growth lowers energy consumption, but raises
$\mathrm{CO}_{2}$ emission. Wasti and Zaidi [19] dedicated their research to find the link between $\mathrm{CO}_{2}$ emission, energy use, trade liberalisation, and gross domestic product in Kuwait for the period 1971-2017. The following results were obtained by using the ARDL model $-\mathrm{CO}_{2}$ emission and energy consumption promote growth; $\mathrm{CO}_{2}$ emission affects the rise in energy consumption; There is a bidirectional causality between pollution and energy consumption; A unidirectional causality exists from income to $\mathrm{CO}_{2}$ emission, trade liberalisation and energy consumption.

Various studies have investigated the links between gross domestic product, energy consumption, and pollution for a group of different countries, regions and individual countries using different models and time periods [20-24]. However, there is a lack of such research and literature related to developing countries, particularly East-European developing countries. The purpose of this paper is to extend literature on this issue and explore the relationships between GDP growth, FDI, TO, capital, final energy consumption (FEC), and pollution (carbon emission) in order to obtain sustainable economic development in Serbia. After examining the links between FDI, TO, GDP growth, capital, final energy consumption, and carbon emission, it should be possible to identify policies and mechanisms that can reduce contamination and obtain sustainable economic development in Serbia.

Serbia is an East-European developing country that has been undergoing the transition process since 2000 and has suffered a lack of domestic capital. Its economic growth is based on FDI and export (trade openness). Since 2007, Serbia has attracted over $€ 31$ billion FDI [25], which has positively influenced Serbian export and income [26]. Domestic energy production, mainly based on fossil fuels, relatively satisfies energy demand. The energy sector is the largest and most influential sector in Serbia and the biggest percentage of production comes from thermal and hydroelectric plants. However, there is a need for modernisation of this sector [27], because Serbian energy system mainly relies on coal. During 1995-2018, the share of solid fossil fuels decreased, while the share of oil and petroleum products increased. Energy consumption in Serbia has a trend similar to GDP. The rise of energy consumption started in 2000. In 2004, energy consumption reached 17.67 Mtoe, but after 2004, consumption started to decline until 2014, when it maintained a steady trend. In 2014, at its lowest, energy consumption was 12.83 Mtoe. After 2014, energy consumption started to rise and in 2018, it was 14.79 Mtoe. Serbia has low energy efficiency and high $\mathrm{CO}_{2}$ emission due to outdated equipment and production based on fossil fuels [28]. Total greenhouse emission in Serbia comes mostly from the energy sector, and mostly from solid and liquid fuels. According to Global Carbon Atlas [29], $\mathrm{CO}_{2}$ emission was 36.14 $\mathrm{MtCO}_{2}$ in $1995,60.21 \mathrm{MtCO}_{2}$ in 2004 , and $45.44 \mathrm{MtCO}_{2}$ in 2018. 
In the future, Serbia should fulfil sustainable development goals, obtain economic growth and decrease $\mathrm{CO}_{2}$ (carbon) emission. It is critical to achieve economic development while facing sustainability challenges such as decrease in environmental pollution. If economic growth increases carbon emission, then the policy measures and regulations should be aimed at $\mathrm{CO}_{2}$ emission reduction, or indirectly, at establishing some of the circular economy actions to address the pollution issue. If FDI positively affects income growth, which includes energy use and pollution, a policy should be made to promote FDI and introduce energy and environmental measures and regulations to decrease carbon emission.

In order to find an acceptable policy for sustainable economic development in Serbia, there is a need to explore energy-growth-environmental nexus. This paper investigates the relationship between GDP, capital, energy consumption, $\mathrm{CO}_{2}$ emission, trade openness, and FDI in Serbia for the period 1995-2018 by applying the Autoregressive distributed lag model (ARDL) and the Granger causality test. The focus of the research is on the role of FDI and pollution in obtaining sustainable economic development. The main research questions are as follows:

RQ1: Are there long and short-run relationships between GDP as a dependent variable and other indicators as independent variables?

RQ2: Is there a causal relationship between the observed variables?

RQ3: Is FDI a significant variable for obtaining sustainable economic growth?

We used ARDL model in order to provide answers to the research questions, since literature review revealed that it is the most commonly employed model for this kind of research. The model is the most sustainable co-integration model for a single country and analyses the significance of the variables. Then we used the Granger causality test to find the causality relationship between the variables of sustainable economic development. The ARDL bound test is used to show long-run and short-run relations among variables, i.e. to present co-integration among them. The model provides the analysis of the linkage between GDP, capital (K), final energy consumption (FEC), $\mathrm{CO}_{2}$ emission $\left(\mathrm{CO}_{2}\right)$, TO, and FDI. GDP was set as the dependent variable in the proposed model, while other observed variables were set as independent. The model with $\mathrm{CO}_{2}$ as the dependent variable was tested, but it did not have satisfactory statistical properties. Also, we used the Granger causality test to determine the directions of causality. The results show a long-run estimation that $\mathrm{K}$, FDI, and TO will increase GDP, while $\mathrm{CO}_{2}$ emission will decrease GDP. Moreover, the findings confirm a short-run causality from FDI and TO (independent variables) to GDP (explained variable). The Granger causality test reveals that FDI has a unidirectional relationship to GDP, $\mathrm{CO}_{2}, \mathrm{FEC}$, and TO. The test also shows that GDP, $\mathrm{CO}_{2}$ emission and FEC have a unidirectional relationship to TO. The results show no link between $\mathrm{K}$ and GDP; $\mathrm{CO}_{2}$ and GDP; FEC and GDP; $\mathrm{CO}_{2}$ and $\mathrm{K}$; FEC and $\mathrm{K} ; \mathrm{FDI}$ and $\mathrm{K}$; TO and $\mathrm{K} ; \mathrm{FEC}$ and $\mathrm{CO}_{2}$. Generally, the results show that FDI and TO are the significant variables for obtaining sustainable economic growth. Therefore, new policies should combine FDI promotion and trade openness with careful supervision of FDI effects on carbon emission to bring sustainable economic development.

The paper is organised as follows. After the Introduction, Section 2 explains data and methodology. Section 3 provides the estimation of the results and discussion. The last section is dedicated to concluding remarks and implications.

\section{Materials and Methods}

Different studies use different variables to explain energy-economic growth nexus. Predominantly, the dependent variable is $\mathrm{CO}_{2}$, and input variable is energy consumption. Beside this one, other variables are: fossil fuels, consumption of non-renewable (fossil fuels) and renewable energy, population, urbanisation, FDI, trade openness, etc. However, there are studies where the model is set in such a way that GDP is the explained variable and independent variables are capital, labour, energy consumption, fossil fuels, $\mathrm{CO}_{2}$, oil prices, renewable and non-renewable energy consumption [6, 30-31, 22, 32].

\section{Data}

In the paper, annual data are used to cover the period 1995-2018 in Serbia. The following data (variables) are applied in the research: gross domestic product (GDP), capital $(\mathrm{K})$, carbon dioxide emission $\left(\mathrm{CO}_{2}\right)$, final energy consumption (FEC), foreign direct investment (FDI), and trade openness (TO). In order to get more reliable results, we applied most useful variables per capita for measuring economic well-being (GDP per capita), total final energy consumption by end users divided by population (Final energy consumption per capita) and total amount of carbon dioxide emission per person in the country (Emissions tonnes $\mathrm{CO}_{2}$ per person). The data are gathered from the World Bank (particularly from the World Development Indicators), Global Carbon Atlas, and Eurostat. The natural logarithm form values of indicators are used for the propose of calculation. Their values are changed for making the results reliable [33]. Table 1 presents the description of variables and source of data.

\section{The Model}

The following equation gives the model used in this study:

$$
\mathrm{GDP}_{\mathrm{t}}=\mathrm{f}\left(\mathrm{K}_{\mathrm{t}}, \mathrm{CO}_{2, \mathrm{t}}, \mathrm{FEC}_{\mathrm{t}}, \mathrm{FDI}_{\mathrm{t}}, \mathrm{TO}_{\mathrm{t}}\right)
$$


Table 1. Detail of variables.

\begin{tabular}{|c|c|c|c|}
\hline Variable Name & Abbreviation & Unit of Measurement & Source \\
\hline Gross domestic product & GDP & GDP per capita (constant 2010 US\$) & WDI \\
\hline Capital & $\mathrm{K}$ & Gross capital formation (constant 2010 US\$) & WDI \\
\hline Carbon dioxide emission & $\mathrm{CO}_{2}$ & Emissions tonnes CO per person $^{2}$ & Global Carbon Atlas \\
\hline Final energy consumption & FEC & Final energy consumption per capita (Europe 2020- & Eurostat \\
\hline Foreign direct investment & FDI & Foreign direct investment, net inflows (\% of GDP) & WDI \\
\hline Trade openness & TO & Trade (\% of GDP) & WDI \\
\hline
\end{tabular}

Source: Authors' presentation.

...where GDP denotes the logarithm of gross domestic product, $\mathrm{K}$ denotes the logarithm of capital, $\mathrm{CO}_{2}$ is the logarithm of carbon dioxide emissions, FEC is the logarithm of final energy consumption, FDI shows the logarithm of foreign direct investment, and TO is the logarithm of trade openness.

The following model combinations were tested:

$$
\begin{aligned}
& \mathrm{K}_{\mathrm{t}}=\mathrm{f}\left(\mathrm{GDP}_{\mathrm{t}}, \mathrm{CO}_{2, \mathrm{t}}, \mathrm{FEC}_{\mathrm{t}}, \mathrm{FDI}_{\mathrm{t}}, \mathrm{TO}_{\mathrm{t}}\right) \\
& \mathrm{CO}_{2, \mathrm{t}}=\mathrm{f}\left(\mathrm{GDP}_{\mathrm{t}}, \mathrm{K}_{\mathrm{t}}, \mathrm{FEC}_{\mathrm{t}}, \mathrm{FDI}_{\mathrm{t}}, \mathrm{TO}_{\mathrm{t}}\right) \\
& \mathrm{FEC}_{\mathrm{t}}=\mathrm{f}\left(\mathrm{GDP}_{\mathrm{t}} \mathrm{K}_{\mathrm{t}}, \mathrm{CO}_{2, \mathrm{t}}, \mathrm{FDI}_{\mathrm{t}}, \mathrm{TO}_{\mathrm{t}}\right) \\
& \mathrm{FDI}_{\mathrm{t}}=\mathrm{f}\left(\mathrm{GDP}_{\mathrm{t}}, \mathrm{K}_{\mathrm{t}}, \mathrm{CO}_{2, \mathrm{t}}, \mathrm{FEC}_{\mathrm{t}}, \mathrm{TO}_{\mathrm{t}}\right) \\
& \mathrm{TO}_{\mathrm{t}}=\mathrm{f}\left(\mathrm{GDP}_{\mathrm{t}}, \mathrm{K}_{\mathrm{t}}, \mathrm{CO}_{2, \mathrm{t}}, \mathrm{FEC}_{\mathrm{t}}, \mathrm{FDI}_{\mathrm{t}}\right)
\end{aligned}
$$

However, not each model combination had satisfactory statistical properties. Therefore, we decided to show only one model, presented by Eq. (1).

The long-run equilibrium relationship between the selected variables is:

$$
\begin{aligned}
\ln G D P_{t}= & c+\alpha \ln K_{t}+\beta \ln C O_{2, t}+\gamma \ln F E C_{t} \\
& +\delta \ln F D I_{t}+\eta \ln T O_{t}+\zeta_{t}
\end{aligned}
$$

In Eq. (2), $t$ is the time trend, and $\zeta$ is white noise error term.

We employed the ARDL model to discuss the first research question (RQ1), which is related to long and short-run relationships between GDP as dependent variables and other independent variables. Pesaran et al. [34] introduced the ARDL model, which does not need all the variables of the same order to be integrated [35]. The ARDL bounds testing approach proved more suitable than other traditional co-integration models. It appears to be flexible regarding stationarity properties of the variables [36]. ARDL is appropriate for both stationary and non-stationary time series. Moreover, ARDL is appropriate for time series with mixed order of integration $(\mathrm{I}(0)$ and $\mathrm{I}(1))$. However, it is very important to ensure that no variable of $\mathrm{I}(2)$, or higher order, is integrated [30]. In the ARDL model, OLS estimation is used to estimate the co-integration relationship, and it is carried out after the appropriate lag order was chosen for the model [37]. Narayan and Smyth [38] applied the ARDL bounds testing for giving consistent and efficient empirical evidence in the cases of small sample data. Therefore, the approach of ARDL bounds testing is suitable for Serbia.

The ARDL model is described by the following equation:

$$
\begin{aligned}
& \Delta \ln G D P_{t}=c_{0}+\psi_{1} \ln G D P_{t-1}+\psi_{2} \ln K_{t-1} \\
& +\psi_{3} \ln \mathrm{CO}_{2, t-1}+\psi_{4} \ln F E C_{t-1}+\psi_{5} \ln F D I_{t-1} \\
& +\psi_{6} \ln T O_{t-1}+\sum_{i=1}^{p} a_{i} \Delta \ln G D P_{t-i}+\sum_{i=1}^{q} b_{i} \Delta \ln K_{t-i} \\
& +\sum_{i=1}^{r} c_{i} \Delta \ln C O_{2, t-i}+\sum_{i=1}^{m} d_{i} \Delta \ln F E C_{t-i} \\
& +\sum_{i=1}^{l} e_{i} \Delta \ln F D I_{t-i}+\sum_{i=1}^{k} f_{i} \Delta \ln T O_{t-i}+\varepsilon_{t}
\end{aligned}
$$

...where $c_{0}$ is a constant coefficient, $\Delta$ presents the first difference of the selected variables, $\varepsilon_{t}$ is the error term, $\psi_{i}$ are the long run coefficients $(\mathrm{i}=1,2,3,4,5,6)$, while $a_{i}, b_{i}, c_{i}, d_{i}, e_{i}$, and $f_{i}$ are the short-run coefficients. The model in equation (3) is ARDL (p, q, r, m, l, k), where p, $\mathrm{q}, \mathrm{r}, \mathrm{m}, \mathrm{l}$, and $\mathrm{k}$ represent the lag length.

The null hypothesis of no co-integration is tested $\psi_{1}=\psi_{2}=\psi_{3}=\psi_{4}=\psi_{5}=\psi_{6}=0$ against the alternative hypothesis of $\psi_{1} \neq \psi_{2} \neq \psi_{3} \neq \psi_{4} \neq \psi_{5} \neq \psi_{6} \neq 0$ in the Eq. (3).

Co-integration tests are conducted by analysing the significance of the variables by applying Wald statistic. In a way similar to Sinha and Shahbaz [39], to test the significance of the associations, we applied the critical values of F-statistic used by Narayan [40] that work well for small samples [39]. For the F-statistic lower than the lower bound value, $\mathrm{H}_{0}$ is not rejected (there is no cointegration). For the F-statistic that falls between lower and upper bounds, the test does not give any conclusion (inconclusive), and for F-statistic that is higher than the upper bound value, $\mathrm{H}_{0}$ is rejected and there is evidence to confirm the co-integration relationship [35].

From the equation (2) we can derive the short-run equation as follows: 


$$
\begin{aligned}
& \Delta \operatorname{lnGDP_{t}}=c_{0}+\sum_{i=1}^{p} a_{i} \Delta \operatorname{lnGDP_{t-i}}+\sum_{i=1}^{q} b_{i} \Delta \ln K_{t-i} \\
& +\sum_{i=1}^{r} c_{i} \Delta \ln C O_{2, t-i}+\sum_{i=1}^{m} d_{i} \Delta \ln F E C_{t-i} \\
& +\sum_{i=1}^{l} e_{i} \Delta l n F D I_{t-i}+\sum_{i=1}^{k} f_{i} \Delta l n T O_{t-i}+\varphi E C T_{t-1}+\varepsilon_{t}
\end{aligned}
$$

The error correction term that is one period lagged is $E C T_{t-1}$. When the residuals of Eq. (2) are computed, $E C T_{t-1}$ is obtained, so $E C T_{t}={ }^{\wedge} \zeta_{t}$. In the case of a longrun relationship, $E C T_{t-1}$ shows the time the variables need to recover their long-run equilibrium from the level in the short-run, where $E C T_{t-1}$ denotes the adjustment speed. Therefore $\varphi$ has to be negative and highly significant. The error correction model is another name for the short-run specification [35].

\section{Causality Test}

In the next step, Granger causality tests were used to provide answers to the second research question (RQ2), i.e. the causal relationship between the observed variables. Causal relationships between variables are commonly found by applying Granger causality tests. It is a statistical hypothesis test used to find if one variable has an effect on another [41]. Granger [42] created a causality test method between $\mathrm{X}$ and $\mathrm{Y}$ variables. Three relationships can be found: $\mathrm{X}$ has an effect on $\mathrm{Y}, \mathrm{Y}$ has an effect on $\mathrm{X}$, and $\mathrm{X}$ and $\mathrm{Y}$ have an effect on each other.

$\mathrm{X}$ 'Granger causes' $\mathrm{Y}$ if lagged and current values of $\mathrm{X}$ improve the foreseeing of the future value of $\mathrm{Y}$. The following model is the simple Granger causality model [43]:

$$
\begin{aligned}
& \Delta Y_{t}=\sum_{i=1}^{n} \alpha_{i} \Delta Y_{t-i}+\sum_{j=1}^{n} \beta_{j} \Delta X_{t-j}+u_{1 t} \\
& \Delta X_{t}=\sum_{i=1}^{n} \gamma_{i} \Delta X_{t-i}+\sum_{j=1}^{n} \delta_{j} \Delta Y_{t-j}+u_{2 t}
\end{aligned}
$$

$\beta_{\mathrm{j}}=0(\mathrm{j}=1, \ldots, \mathrm{n})(\mathrm{j}=1, \ldots, \mathrm{n})$ is the null hypothesis in Eq. (5), interpreting that " $\Delta \mathrm{X}$ does not Granger cause $\Delta \mathrm{Y}^{\prime}$. In a similar way, $\delta \mathrm{j}=0(\mathrm{j}=1, \ldots, \mathrm{n})$ is the null hypothesis in Eq. (6), meaning that " $\Delta \mathrm{Y}$ does not Granger cause $\Delta \mathrm{X}$." F-statistics are used to determine whether the null hypothesis will be rejected or not [43].

\section{Results and Discussion}

\section{Estimation Results}

We explored the stationarity status of the selected variables using two different unit root tests. One is the Augmented Dickey-Fuller (ADF) and the other is Phillips-Perron (PP). If the value of a time-series data has a tendency to regain its long-run average value, it is called stationary and its properties are not influenced by the change in time. On the other hand, a non-stationary time series does not have a tendency to regain its long- run average value, so variance and co-variance change over time, too [43]. ADF and PP tests differ only in the fact that ADF deals only in autocorrelation, while PP deals in both autocorrelation and heteroskedasticity [44].

The results of ADF and PP tests on integration properties of the natural $\log$ value of each variable (lnGDP, $\operatorname{lnK}, \ln \mathrm{CO}_{2}, \operatorname{lnFEC}, \operatorname{lnFDI}$, and $\operatorname{lnTO}$ ) for Serbia are shown in Table 2. The results reveal that all selected variables are non-stationary at level, they are integrated of order one or I(1), except lnFDI, which is stationary at the level or $\mathrm{I}(0)$, and InFEC variable is mixed $\mathrm{I}(0)$ and $\mathrm{I}(1)$. Yet, the stationary property is not revealed before taking the first difference of the variables [30]. We used the PP and ADF tests to ensure that no series is included of order 2, i.e. I(2) to justify the suitableness of the ARDL bounds test approach to co-integration [37].

Prior to ARDL bound testing, the optimal lag length has to be found by using different criteria (see Table 3). The findings in Table 3 point that the most advisable lag value for the co-integration model is lag 2 .

In this study, for choosing the ARDL model, we used AIC [45] and SIC [46]. Fig. 1 presents possible ARDL models according to the AIC (left side) and SIC (right side). The ARDL $(1,2,2,2,2,1)$ is selected because for this model, AIC and SIC have the lowest value.

After determining optimal lag length, F-test was employed to explore the long-run co-integration between the variables. Table 4 presents the outcomes of the approach of ARDL bounds testing to co-integration. The results show that F-statistic (5.199) is higher than the upper critical bound proposed by Narayan [40], at 5 per cent level. We can reject the null hypothesis of no co-integration relationship. This result confirms that, in the case of Serbia, the variables are co-integrated in the long run, which is the answer to research question RQ1, i.e. there is a long-run relationship between GDP and other observed variables.

Additionally, the results of diagnostic tests (Table 4) for the selected ARDL model prove no serial correlation (according to Breusch-Godfrey Serial Correlation LM Test), and heteroskedasticity (according to the ARCH test) in residuals of the model. Further, the Ramsey Reset test let us know that there is evidence that the model does not suffer from misspecification.

According to Cumulative Sum test (CUSUM) and Cumulative Sum of Squares test (CUSUMSQ) developed by Brown et al. [47], ARDL model $(1,2,2,2,2,1)$ is stable over the observed period (see Fig. 2). This model is applicable since the distribution of the recursive residuals falls between the boundaries.

Table 5 presents a long-run estimation and indicates that capital is significant at the $1 \%$ level to explain GDP, while $\mathrm{CO}_{2}$ emission coefficient is negative (at the $5 \%$ level significance). The following studies confirm these results. Bilan et al. [48] demonstrate that capital affects economic growth in EU candidate countries. The study [49] verifies the negative long-run linkage 
Table 2. Unit root test.

\begin{tabular}{|c|c|c|c|c|c|c|c|}
\hline \multirow{3}{*}{\multicolumn{2}{|c|}{$\begin{array}{c}\text { Unit root test } \\
\text { Variables }\end{array}$}} & \multicolumn{6}{|c|}{ Level } \\
\hline & & \multicolumn{2}{|c|}{ Without intercept and trend } & \multicolumn{2}{|c|}{ With intercept } & \multicolumn{2}{|c|}{ With intercept and trend } \\
\hline & & ADF & PP & $\mathrm{ADF}$ & PP & ADF & PP \\
\hline \multirow{2}{*}{$\operatorname{lnGDP}$} & t statistics & 2.500 & 3.456 & -0.733 & -0.733 & -3.621 & -1.502 \\
\hline & p value & 0.995 & 1.000 & 0.819 & 0.819 & 0.055 & 0.799 \\
\hline \multirow{2}{*}{$\ln K$} & $\mathrm{t}$ statistics & 0.938 & 1.102 & -1.199 & -1.271 & -1.979 & -2.175 \\
\hline & p value & 0.902 & 0.924 & 0.657 & 0.625 & 0.582 & 0.480 \\
\hline \multirow[t]{2}{*}{$\operatorname{lnCO}_{2}$} & t statistics & 0.181 & 0.416 & -3.017 & -3.004 & -2.866 & -2.866 \\
\hline & $\mathrm{p}$ value & 0.729 & 0.795 & 0.048 & 0.049 & 0.191 & 0.191 \\
\hline \multirow{2}{*}{$\operatorname{lnFEC}$} & t statistics & 0.837 & 0.815 & -4.020 & -3.907 & -3.726 & -3.713 \\
\hline & $\mathrm{p}$ value & 0.885 & 0.881 & 0.006 & 0.007 & 0.041 & 0.042 \\
\hline \multirow{2}{*}{$\operatorname{lnFDI}$} & t statistics & -3.529 & -3.457 & -3.686 & -3.611 & -4.732 & -4.735 \\
\hline & p value & 0.001 & 0.001 & 0.012 & 0.014 & 0.005 & 0.005 \\
\hline \multirow{2}{*}{$\ln \mathrm{TO}$} & t statistics & 1.233 & 2.192 & -1.062 & -2.418 & -8.448 & -3.951 \\
\hline & $\mathrm{p}$ value & 0.939 & 0.991 & 0.711 & 0.148 & 0.000 & 0.026 \\
\hline & & \multicolumn{6}{|c|}{ First Difference } \\
\hline \multirow{2}{*}{$\Delta \operatorname{lnGDP}$} & $\mathrm{t}$ statistics & -2.048 & -3.005 & -4.222 & -4.222 & -4.156 & -4.156 \\
\hline & $\mathrm{p}$ value & 0.041 & 0.005 & 0.004 & 0.004 & 0.018 & 0.018 \\
\hline \multirow{2}{*}{$\Delta \ln K$} & $\mathrm{t}$ statistics & -3.740 & -3.649 & -3.750 & -3.643 & -3.654 & -3.523 \\
\hline & p value & 0.001 & 0.001 & 0.010 & 0.013 & 0.048 & 0.062 \\
\hline \multirow{2}{*}{$\Delta \operatorname{lnCO}{ }_{2}$} & $\mathrm{t}$ statistics & -6.236 & -6.808 & -6.099 & -6.642 & -6.016 & -6.814 \\
\hline & $\mathrm{p}$ value & 0.000 & 0.000 & 0.000 & 0.000 & 0.000 & 0.000 \\
\hline \multirow{2}{*}{$\Delta \ln F E C$} & t statistics & -5.120 & -7.142 & -4.938 & -6.864 & -4.619 & -6.017 \\
\hline & $\mathrm{p}$ value & 0.000 & 0.000 & 0.001 & 0.000 & 0.007 & 0.000 \\
\hline \multirow{2}{*}{$\Delta \operatorname{lnFDI}$} & t statistics & -12.802 & -11.217 & -13.416 & -11.774 & -15.345 & -15.345 \\
\hline & $\mathrm{p}$ value & 0.000 & 0.000 & 0.000 & 0.000 & 0.000 & 0.000 \\
\hline \multirow{2}{*}{$\Delta \ln \mathrm{TO}$} & t statistics & -5.557 & -5.926 & -5.603 & -13.475 & -5.414 & -12.905 \\
\hline & $\mathrm{p}$ value & 0.000 & 0.000 & 0.000 & 0.000 & 0.001 & 0.000 \\
\hline
\end{tabular}

Note: ADF denotes Augmented Dickey-Fuller test; PP notes Phillips-Perron test. $\Delta$ is the first difference operator of the selected variables. Source: Authors' calculation.

Table 3. Lag Order Selection Criteria.

\begin{tabular}{|c|c|c|c|c|c|c|}
\hline Lag & LogL & LR & FPE & AIC & SIC & HQ \\
\hline 0 & 23.949 & NA & 0.010 & -1.795 & -1.496 & -1.737 \\
\hline 1 & 42.552 & 24.185 & 0.002 & -3.555 & -3.207 & -3.487 \\
\hline 2 & 48.281 & $6.875^{*}$ & $0.001^{*}$ & $-4.028^{*}$ & $-3.630^{*}$ & $-3.950^{*}$ \\
\hline 3 & 48.944 & 0.729 & 0.001 & -3.994 & -3.546 & -3.907 \\
\hline 4 & 48.983 & 0.039 & 0.001 & -3.898 & -3.400 & -3.801 \\
\hline
\end{tabular}

Notes: * demonstrates lag order selected by the criterion; LR presents sequential modified LR test statistic (at 5\% level); FPE is Final prediction error; AIC is Akaike information criterion; SIC indicates Schwarz information criterion; HQ stays for Hannan-Quinn information criterion. Source: Authors' calculation. 


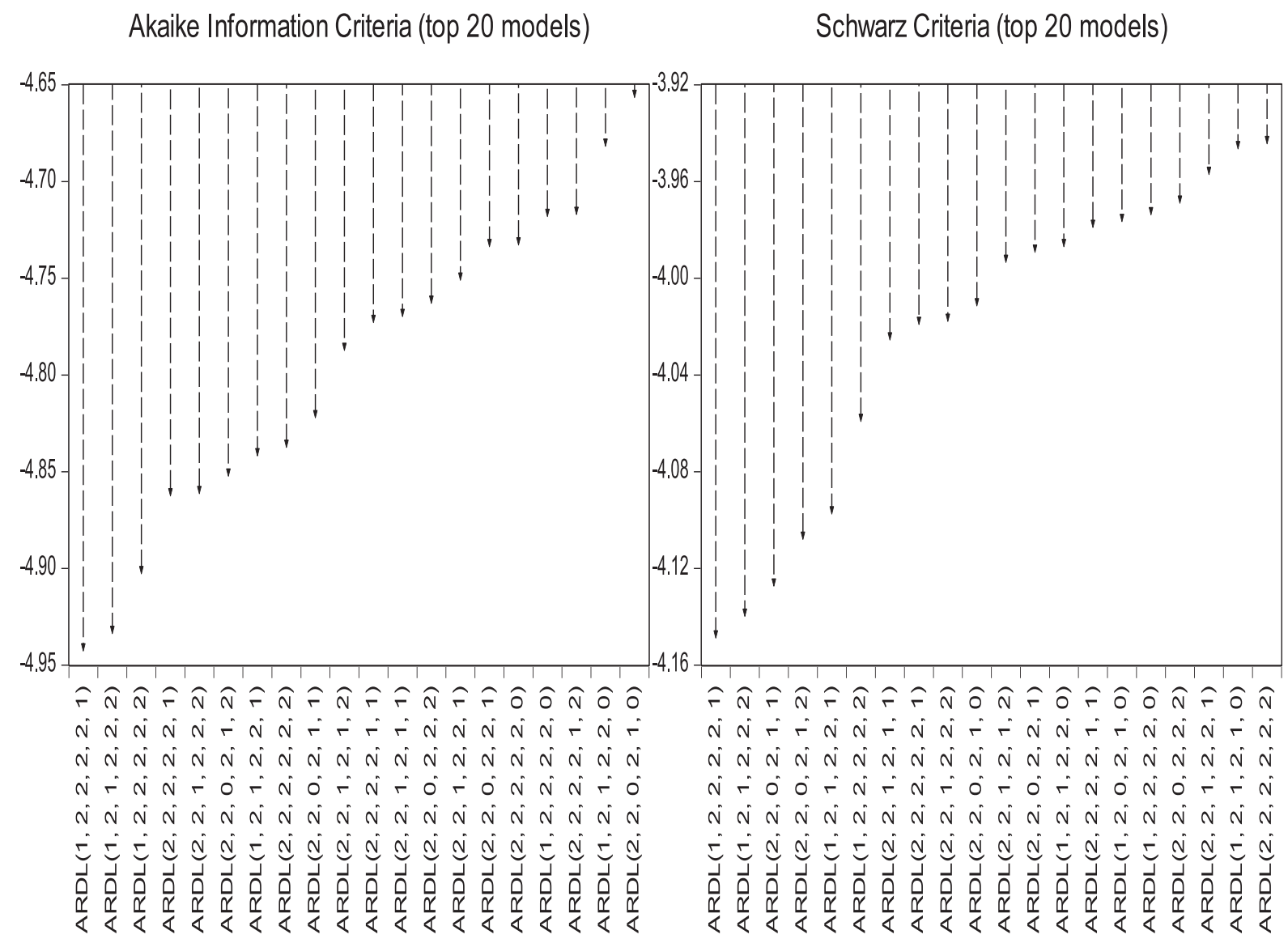

Fig. 1. ARDL model selection criterion. Source: Authors' calculation.

between income and $\mathrm{CO}_{2}$ emission in EU countries. Foreign direct investment and trade openness variables have positive values and are significant at the 5\% level, while constant term and final energy consumption are insignificant in the long-run. The results that FDI influences GDP correspond to the finding of Sun et al. [50]. A $10 \%$ growth in $\mathrm{CO}_{2}$ emissions would decrease GDP by $5 \%$, and a $10 \%$ growth in the capital would

Table 4. The results of the ARDL co-integration test and diagnostic tests.

\begin{tabular}{|c|c|c|}
\hline \multicolumn{3}{|c|}{ Bound testing to co-integration } \\
\hline Model estimated & Lags & F-stat \\
\hline $\mathrm{GDP}=\mathrm{f}\left(\mathrm{K}, \mathrm{CO}_{2}, \mathrm{FEC}, \mathrm{FDI}, \mathrm{TO}\right)$ & $(1,2,2,2,2,1)$ & $5.199 *$ \\
\hline \multirow{3}{*}{ Significant levels } & \multicolumn{2}{|c|}{ Critical values $(\mathrm{T}=30)$} \\
\hline & Lower bound & Upper bounds \\
\hline & $\mathrm{I}(0)$ & $\mathrm{I}(1)$ \\
\hline $1 \%$ level & 4.537 & 6.370 \\
\hline $5 \%$ level & 3.125 & 4.608 \\
\hline $10 \%$ level & 2.578 & 3.858 \\
\hline \multicolumn{3}{|c|}{ Diagnostic tests } \\
\hline Serial Correlation & Heteroskedasticity & Ramsey Reset \\
\hline $0.075(0.929)$ & $0.995(0.390)$ & $1.216(0.387)$ \\
\hline
\end{tabular}

Notes: Critical bound values rely on Narayan (2005). Values are with unrestricted intercept and no trend. p-value is in parentheses.

* Denotes significance at 5\% level. Source: Authors' calculation. 


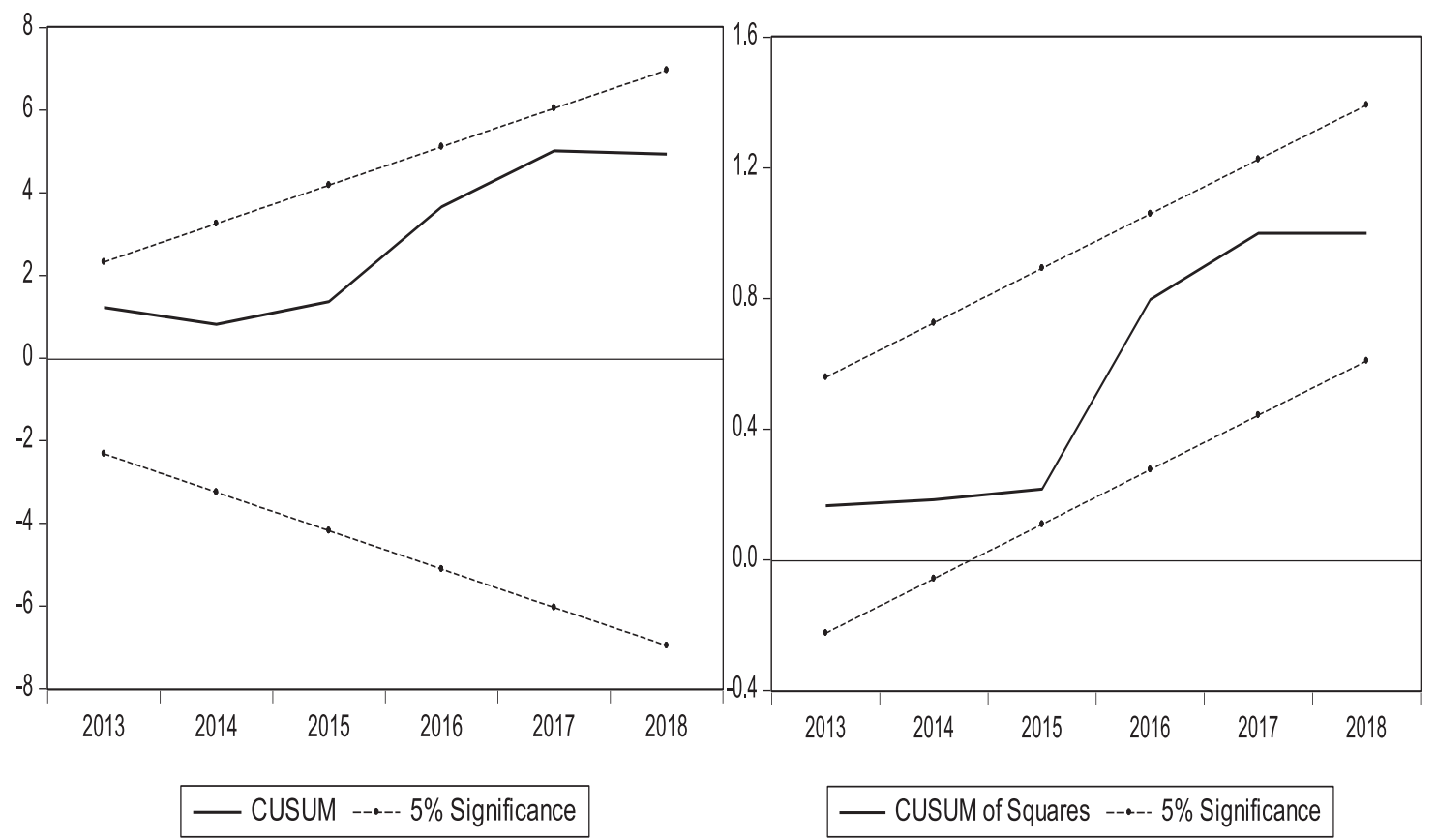

Fig. 2. Stability diagnostics of ARDL. Source: Authors' calculation.

raise GDP by $3 \%$. Similarly, a $10 \%$ growth in foreign direct investment, and trade openness would boost GDP by $0.2 \%$ and $3 \%$, respectively.

First, we determined that the variables are cointegrated. Then we estimated the Error Correction Model (ECM) within the ARDL framework to find the short-run coefficient of the variables' relationships [6]. Table 6 presents a short-run estimation, the standard diagnostic tests of the model, and the standard Wald test on the coefficient. The error correction term $\left(E C T_{t-1}\right)$ is negative and statistically significant at the $1 \%$ level, and it supports the co-integration hypothesis. $E C T_{t-1}$ has the value of $52.8 \%$ and it is the speed of adjustment. Also, the system is getting adapted over

Table 5. Long-run estimation.

\begin{tabular}{|c|c|c|}
\hline \multicolumn{3}{|c|}{ Dependent variable: lnGDP } \\
\hline Variable & Coefficient & Prob. \\
\hline $\mathrm{C}$ & 0.810 & 0.777 \\
\hline $\operatorname{lnK}$ & 0.327 & 0.004 \\
\hline $\operatorname{lnCO} 2$ & -0.523 & 0.083 \\
\hline $\operatorname{lnFEC}$ & -0.035 & 0.930 \\
\hline $\operatorname{lnFDI}$ & 0.017 & 0.044 \\
\hline $\operatorname{lnTO}$ & 0.321 & 0.012 \\
\hline $\mathrm{R}^{2}$ & 0.905 & \\
\hline Adjusted $\mathrm{R}^{2}$ & 0.879 & \\
\hline F-statistic & 34.285 & 0.000 \\
\hline
\end{tabular}

Source: Authors' calculation. the long-run equilibrium at the speed of $52.8 \%$. A significant error correction term with negative value shows that the suiting process to regain equilibrium is highly reliable [30]. The existence of causality between variables in the short run can be observed. Precisely, the Wald test suggested the case of the short-run causal relationship from independent variables (foreign direct investment and trade openness) to the explained variable (GDP). These results are the same as Hossain's findings that short-run causality trade openness and GDP exist in newly industrialised countries [51]. These findings provide the answer to research question RQ1, i.e. there is a short-run relationship between GDP and other observed variables. According to the diagnostic tests, it may be stated that the model is correctly specified (no serial correlation, no misspecification, no heteroskedasticity), and it is stable (see Fig. 3).

Fig. 3 presents the CUSUM and CUSUMSQ test for a short-run model or error correction model (ECM). As the CUSUM and CUSUMSQ tests stay within the $5 \%$ critical lines, this model is stable over the observed period.

Table 7 shows the results of the Granger causality test, which was used to examine the causality directions. Before examining Granger's causality, we needed to identify the stationarity of the chosen variables. As found by using ADF and PP tests, most variables were non-stationary, or they had a unit root at the level. Then we transformed them into stationary processes using the first difference. After obtaining the stationary property taking the first variables' difference, Granger causality test can be applied.

Table 7 shows that the null hypothesis about noncausality is rejected only in seven cases. It indicates that: FDI has a unidirectional relationship to GDP (at 
Table 6. Short-run estimation.

\begin{tabular}{|c|c|c|}
\hline \multicolumn{3}{|c|}{ Dependent variable: $\Delta \operatorname{lnGDP}$} \\
\hline Variable & Coefficient & Prob. \\
\hline $\mathrm{C}$ & 0.043 & 0.004 \\
\hline$\Delta \ln \operatorname{GDP}(-1)$ & 0.496 & 0.133 \\
\hline$\Delta \ln K(-1)$ & -0.083 & 0.231 \\
\hline$\Delta \operatorname{lnK}(-2)$ & -0.098 & 0.140 \\
\hline$\Delta \operatorname{lnCO}_{2}(-1)$ & 0.346 & 0.078 \\
\hline$\Delta \operatorname{lnCO}_{2}(-2)$ & 0.291 & 0.057 \\
\hline$\Delta \operatorname{lnFEC}(-1)$ & -0.171 & 0.472 \\
\hline$\Delta \operatorname{lnFEC}(-2)$ & -0.204 & 0.272 \\
\hline$\Delta \operatorname{lnFDI}(-1)$ & -0.020 & 0.022 \\
\hline$\Delta \operatorname{lnFDI}(-2)$ & -0.017 & 0.003 \\
\hline$\Delta \ln \mathrm{TO}(-1)$ & -0.103 & 0.055 \\
\hline ECT(-1) & -0.528 & 0.010 \\
\hline $\mathrm{R}^{2}$ & 0.825 & \\
\hline Adjusted $\mathrm{R}^{2}$ & 0.611 & \\
\hline F-statistic & 3.860 & 0.026 \\
\hline Diagnostic tests & F-statistic & Prob. \\
\hline Serial Correlation & 1.304 & 0.330 \\
\hline Heteroskedasticity & 0.320 & 0.731 \\
\hline Ramsey Reset & 2.109 & 0.185 \\
\hline \multicolumn{3}{|l|}{ Wald test } \\
\hline Null Hypothesis & F-statistic & Prob. \\
\hline$C(3)=C(4)=0$ & 2.036 & 0.186 \\
\hline$C(5)=C(6)=0$ & 2.778 & 0.115 \\
\hline$C(7)=C(8)=0$ & 1.055 & 0.388 \\
\hline$C(9)=C(10)=0$ & 9.175 & 0.007 \\
\hline$C(11)=0$ & 4.880 & 0.054 \\
\hline
\end{tabular}

Note: $\Delta$ is the first difference operator of the selected variables. Source: Authors' calculation.

a significance level of 1\%), GDP has a unidirectional relationship to trade openness (at the $1 \%$ level of significance), FDI has a unidirectional relationship to carbon emission (at a significance level of $5 \%$ ), $\mathrm{CO}_{2}$ emission has an unidirectional relationship to trade openness (at a significance level of $10 \%$ ), FDI has a unidirectional relationship to the consumption of final energy (at the 5\% level of significance), final energy consumption has a unidirectional relationship to trade openness (at a significance level of 5\%), and FDI has a unidirectional relationship to trade openness (at the 10\% level of significance). We do not reject null hypotheses about non-causality in eight cases that demonstrate no relationship between $\mathrm{K}$ and GDP; FEC and GDP; $\mathrm{CO}_{2}$ and $\mathrm{K}$; $\mathrm{FEC}$ and $\mathrm{K} ; \mathrm{CO}_{2}$ and GDP; FDI and $\mathrm{K}$; TO and $\mathrm{K} ; \mathrm{FEC}$ and $\mathrm{CO}_{2}$. These results provide positive answers to second and third research questions (RQ2 and RQ3), i.e. there is causality relationship between selected variables, and FDI is a significant variable for obtaining sustainable economic growth.

\section{Discussion}

The investigation of the relationship between the chosen variables should provide an appropriate policy for establishing sustainable economic development. This study confirms that FDI and TO have a positive long and short-run impact on GDP, which is the answer to RQ1 that there is a long and short-run relationship between GDP and other selected variables. Also, findings respond to RQ2 and RQ3 showing that FDI has a unidirectional relationship to GDP, and that GDP has a unidirectional relationship to trade openness. This outcome confirms Hossain [52] and shows that FDI and TO are drivers of economic growth. The study [52] indicates that FDI has a unidirectional relationship to $\mathrm{CO}_{2}$ emission, final energy consumption and trade openness. These findings imply that the influence of FDI on pollution is in agreement with the results of Behera and Dash [53], Hoffman et al. [54], Zakarya et al. [55]. However, some findings have yielded different results. Al-mulali and Tang [56] show that FDI does not impact pollution in the GCC countries. Demena and Afesorgbor [57] point out that FDI reduces contamination due to green investments. According to the results related to Serbia, it is clear that even though FDI has a supporting role in achieving economic growth through trade openness, it also increases energy demand and pollution. FDI supports sustainable development goals like sustainable growth, energy, infrastructure, innovation and climate changes. However, investments in dirty technologies and lack of environmental regulations can cause $\mathrm{CO}_{2}$ emission. So, establishment and enforcement of environmental laws, regulations and efficient energy use could bring about economic growth and decrease air pollution.

Even though the aim of this research is to show energy-environmental nexus, the research reveals no link between final energy consumption and carbon emission, no causality between final energy consumption and income, and no linkage between final energy consumption and capital. This result does not confirm the findings in another study [58] that consumption of energy influences higher economic growth, nor the bidirectional relationship from GDP growth to energy use [59]. Apart from these two findings, the result of our study that presents no causality between energy consumption and GDP is along with the findings of Menegaki [60]. According to the results, the energy is not significant for obtaining economic growth.

Trade openness may have both positive and negative effects on sustainable development. Trade openness 


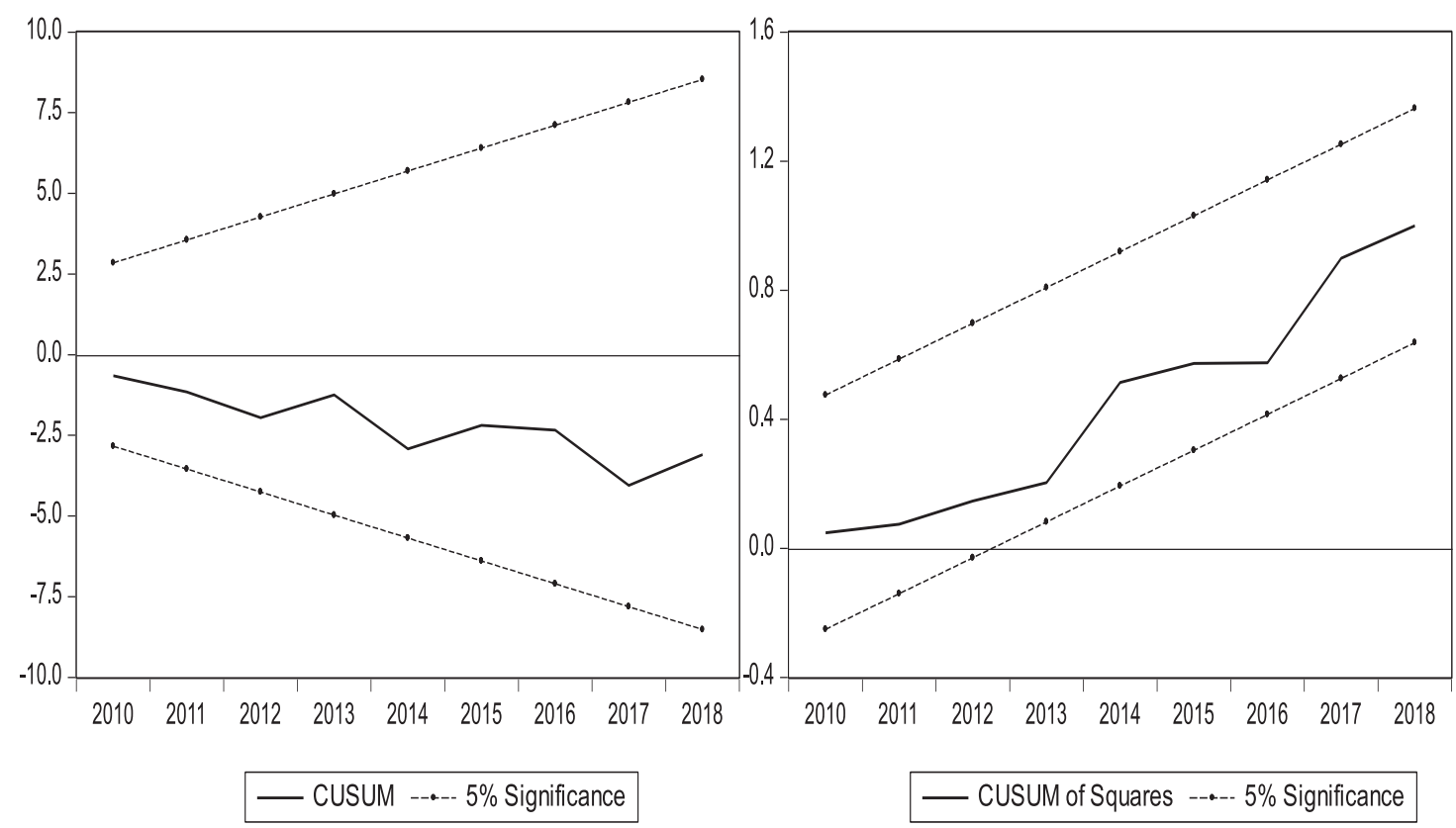

Fig. 3. Stability diagnostics of short-run model. Source: Authors' calculation.

affects environmental degradation with economic expansion. However, at a certain level of economic progress, a country may decide that clean industries and production can change the structure of output and improve environmental quality. The research shows that $\mathrm{CO}_{2}$ emission has a unidirectional relationship to trade openness. Contrary to this, studies [61, 62] show that trade openness affects $\mathrm{CO}_{2}$ emission. The studies explain this relationship due to the manufacturing sector which has a high share in GDP and is oriented toward exports. Also, export products are output from non-clean capacities [63]. Energy and trade have both direct and indirect effects on sustainable economic development. Energy consumption can be prerequisite for growth (trade), and/or the consequence of economic growth (trade) that will influence environmental degradation and pollution. Trade openness increases production due to higher export, but a rise in energy consumption increases pollution. Therefore, identifying the link between trade openness and energy is required to support sustainable economic growth, job creation, welfare, energy efficiency and clean technologies. This study shows that final energy consumption has a unidirectional relationship to trade openness in Serbia. The finding of Tiba and Frikha [64] confirms this relationship as well.

Serbia has outdated capacities and lack of domestic capital. In order to obtain modernisation and new capital equipment, Serbia needs investments. Therefore, capital does not have impact on GDP in the short run, but has in the long run. The finding of this study shows non-causality between capital and GDP. However, Saint Akadiri et al. [31] discovered a direct link between capital and GDP. According to the findings related to Serbia, there is no relation between FDI and capital, trade openness and capital, and $\mathrm{CO}_{2}$ emission and capital. Acaravci and Ozturk [65] identified no relationship between energy use and income, which confirms the findings of no causality between pollution and GDP in Serbia.

Serbia should simultaneously provide economic growth and carbon emission decrease as a path to sustainable development. The results of our paper show the link between FDI, trade openness, $\mathrm{CO}_{2}$ emission, income, energy consumption, and capital. The direction and relationship between variables can help policymakers decide which model of growth to choose and which factors to apply to achieve sustainable economic development. According to the results, FDI and TO have a significant role in obtaining economic growth. They can tackle sustainable economic issues like poverty, clean energy, and efficient use of energy resources and clean industry.

\section{Conclusions}

The three most important factors in achieving economic growth are capital, labour and energy. However, on their way to achieving economic growth, countries have to cope with the problems such as limited traditional and energy resources, environmental depletion and pollution. It is not possible to obtain sustainable development without reconciling these two sides of economic growth. In the interest of designing energy, environmental and economic policies, it is essential to search for the link between growth, capital, energy consumption, carbon emission, FDI, and trade openness. This paper investigates the link between these variables in Serbia for the period 1995-2018. First, the 
Table 7. Granger Causality Tests.

\begin{tabular}{|c|c|c|c|c|}
\hline \multicolumn{2}{|c|}{$\begin{array}{l}\text { Null Hypothesis: } \\
\text { " } \Delta \mathrm{X} \text { does not Granger } \\
\text { cause } \Delta \mathrm{Y} "\end{array}$} & \multirow[t]{2}{*}{ F-Statistic } & \multirow[t]{2}{*}{ Prob. } & \multirow[t]{2}{*}{ Decision } \\
\hline$\Delta \mathrm{X}$ & $\Delta \mathrm{Y}$ & & & \\
\hline$\Delta \ln \mathrm{K}$ & $\Delta \operatorname{lnGDP}$ & 1.832 & 0.192 & Accept \\
\hline$\Delta \operatorname{lnGDP}$ & $\Delta \ln K$ & 0.422 & 0.663 & Accept \\
\hline$\Delta \operatorname{lnCO}_{2}$ & $\Delta \operatorname{lnGDP}$ & 0.079 & 0.925 & Accept \\
\hline$\Delta \operatorname{lnGDP}$ & $\Delta \operatorname{lnCO}{ }_{2}$ & 0.529 & 0.600 & Accept \\
\hline$\Delta \operatorname{lnFEC}$ & $\Delta \operatorname{lnGDP}$ & 0.390 & 0.683 & Accept \\
\hline$\Delta \operatorname{lnGDP}$ & $\triangle \operatorname{lnFEC}$ & 0.104 & 0.902 & Accept \\
\hline$\Delta \operatorname{lnFDI}$ & $\Delta \operatorname{lnGDP}$ & 7.503 & 0.005 & Reject \\
\hline$\Delta \operatorname{lnGDP}$ & $\Delta \operatorname{lnFDI}$ & 0.560 & 0.582 & Accept \\
\hline$\Delta \ln T O$ & $\Delta \operatorname{lnGDP}$ & 0.059 & 0.943 & Accept \\
\hline$\Delta \operatorname{lnGDP}$ & $\Delta \ln \mathrm{TO}$ & 9.355 & 0.002 & Reject \\
\hline$\Delta \operatorname{lnCO}_{2}$ & $\Delta \ln K$ & 0.720 & 0.502 & Accept \\
\hline$\Delta \ln \mathrm{K}$ & $\Delta \ln \mathrm{CO}_{2}$ & 0.017 & 0.983 & Accept \\
\hline$\Delta \operatorname{lnFEC}$ & $\Delta \ln K$ & 1.997 & 0.168 & Accept \\
\hline$\Delta \ln K$ & $\Delta \operatorname{lnFEC}$ & 0.245 & 0.786 & Accept \\
\hline$\Delta \operatorname{lnFDI}$ & $\Delta \ln \mathrm{K}$ & 0.523 & 0.603 & Accept \\
\hline$\Delta \ln K$ & $\Delta \operatorname{lnFDI}$ & 0.090 & 0.915 & Accept \\
\hline$\Delta \ln \mathrm{TO}$ & $\Delta \ln \mathrm{K}$ & 0.705 & 0.509 & Accept \\
\hline$\Delta \ln K$ & $\Delta \ln \mathrm{TO}$ & 0.908 & 0.423 & Accept \\
\hline$\Delta \operatorname{lnFEC}$ & $\Delta \ln \mathrm{CO}_{2}$ & 0.125 & 0.883 & Accept \\
\hline$\Delta \operatorname{lnCO}_{2}$ & $\Delta \operatorname{lnFEC}$ & 0.199 & 0.822 & Accept \\
\hline$\Delta \operatorname{lnFDI}$ & $\Delta \operatorname{lnCO}{ }_{2}$ & 3.978 & 0.040 & Reject \\
\hline$\Delta \operatorname{lnCO}_{2}$ & $\Delta \operatorname{lnFDI}$ & 0.125 & 0.883 & Accept \\
\hline$\Delta \ln \mathrm{TO}$ & $\Delta \ln \mathrm{CO}_{2}$ & 0.018 & 0.983 & Accept \\
\hline$\Delta \operatorname{lnCO}_{2}$ & $\Delta \ln \mathrm{TO}$ & 3.176 & 0.069 & Reject \\
\hline$\Delta \operatorname{lnFDI}$ & $\Delta \operatorname{lnFEC}$ & 5.499 & 0.015 & Reject \\
\hline$\Delta \operatorname{lnFEC}$ & $\Delta \operatorname{lnFDI}$ & 0.243 & 0.787 & Accept \\
\hline$\Delta \operatorname{lnTO}$ & $\Delta \operatorname{lnFEC}$ & 0.286 & 0.755 & Accept \\
\hline$\Delta \operatorname{lnFEC}$ & $\Delta \operatorname{lnTO}$ & 4.339 & 0.031 & Reject \\
\hline$\Delta \operatorname{lnTO}$ & $\Delta \operatorname{lnFDI}$ & 0.707 & 0.508 & Accept \\
\hline$\Delta \operatorname{lnFDI}$ & $\Delta \operatorname{lnTO}$ & 3.521 & 0.054 & Reject \\
\hline
\end{tabular}

Note: $\Delta$ is the first difference operator of the selected variables. Source: Authors' calculation.

study shows long and short-run relationships between GDP as a dependent variable and other indicators as independent variables (RQ1). The results present a longrun estimation that FDI and TO will increase GDP, while pollution will decrease it. Moreover, there is shortrun causality from FDI and TO to GDP. Second, there is a causal relationship between the observed variables (RQ2). This paper's findings show a unidirectional relationship from $\mathrm{FDI}$ to $\mathrm{CO}_{2}$ emission, income, final energy consumption, and trade openness. Besides, final energy consumption, $\mathrm{CO}_{2}$ emission and GDP, have a unidirectional relationship to trade openness. However, no relationship occurs between: capital and GDP, $\mathrm{CO}_{2}$ emission and GDP, final energy consumption and GDP, carbon emission and capital, final energy consumption and capital, foreign direct investment and capital, trade openness and capital, and final energy consumption utilisation and $\mathrm{CO}_{2}$ emission. Finally, FDI is a significant variable for obtaining sustainable economic growth (RQ3).

The results imply that the policies should include FDI promotion and trade openness, while FDI effects on $\mathrm{CO}_{2}$ emission should be better supervised. The implementation of these measures should help obtaining sustainable economic development. FDI should be one of the key drivers of sustainable economic development in Serbia. Serbia has based its growth on FDI and export. That is why it has to attract FDI to generate productivity and income growth, taking care that FDI is oriented towards clean production and advanced technologies. The government should introduce regulations, environmental taxes and subsidies aimed towards reducing $\mathrm{CO}_{2}$ emission. Environmental policy should be directed towards renewable resources and energy efficiency improvement. Regulations and agreements concerning energy and environment issues should provide a decrease in environmental pollution. One of the suggestions is to establish a circular economy to apply the concept of reducing, reusing, and recycling resources, waste prevention, using sustainable products, prolonging product life cycle, and consuming through sharing platforms. Some of these aspects are connected with sustainable development goals (SDGs) through energy, economic growth, industry, responsible consumption, production, and climate changes. To address economic and environmental pollution issues, sustainable financing and green investments should be provided. Finally, FDI should be regarded as one of the critical issues in Serbian economic development, together with environmental and energy policies. In this way, some SDGs will be addressed directly, and some indirectly. The next research will address the causality between non-renewable energy, income, renewable energy consumption, and carbon emission in the EU member and candidate countries to compare advanced and developing countries and observe how they cope with sustainability challenges.

\section{Acknowledgements}

We are thankful for the support of the Ministry of Education, Science and Technological Development of the Republic of Serbia. 


\section{Conflict of Interest}

The authors declare no conflict of interest.

\section{References}

1. STANKOVIC S., VASKOVIC V., PETROVIC N., RADOJICIC Z., LJUBOJEVIC M. Urban traffic air pollution: case study of Banja Luka. Environmental Engineering \& Management Journal (EEMJ). 14 (12), 2783, 2015.

2. RAI P.K. Biodiversity of roadside plants and their response to air pollution in an Indo-Burma hotspot region: implications for urban ecosystem restoration. Journal of Asia-Pacific Biodiversity. 9 (1), 47, 2016.

3. UKAOGO P.O., EWUZIE U., ONWUKA C.V. Environmental pollution: causes, effects, and the remedies. Microorganisms for Sustainable Environment and Health. 419, 2020.

4. ADEWUYI A.O., AWODUMI O.B. Renewable and nonrenewable energy-growth-emissions linkages: Review of emerging trends with policy implications. Renewable and Sustainable Energy Reviews. 69, 275, 2017.

5. ADEDOYIN F.F., ZAKARI A. Energy consumption, economic expansion, and $\mathrm{CO}_{2}$ emission in the UK: The role of economic policy uncertainty. Science of the Total Environment. 738, 140014, 2020.

6. APPIAH M.O. Investigating the multivariate Granger causality between energy consumption, economic growth and $\mathrm{CO}_{2}$ emissions in Ghana. Energy Policy. 112, 198, 2018.

7. YAW NAMINSE E., ZHUANG J. Economic Growth, Energy Intensity, and Carbon Dioxide Emissions in China. Polish Journal of Environmental Studies. 27 (5), 20193, 2018.

8. SHAHEEN A., SHENG J., ARSHAD S., SALAM S., HAFEEZ M. The Dynamic Linkage between Income, Energy Consumption, Urbanization and Carbon Emissions in Pakistan. Polish Journal of Environmental Studies. 29 (1), 267, 2020.

9. ZHOU Y., FU J., KONG Y., WU R. How foreign direct investment influences carbon emissions, based on the empirical analysis of Chinese urban data. Sustainability. 10, 2163, 2018

10. LEE J.W. The contribution of foreign direct investment to clean energy use, carbon emissions and economic growth. Energy Policy. 55, 483, 2013.

11. SBIA R., SHAHBAZ M., HAMDI H. A contribution of foreign direct investment, clean energy, trade openness, carbon emissions and economic growth to energy demand in UAE. Economic modelling. 36, 191, 2014.

12. SEBRI M., BEN-SALHA O. On the causal dynamics between economic growth, renewable energy consumption, $\mathrm{CO}_{2}$ emissions and trade openness: Fresh evidence from BRICS countries. Renewable and Sustainable Energy Reviews. 39, 14, 2014.

13. ANSARI M.A., HAIDER S., KHAN N.A. Does trade openness affects global carbon dioxide emissions. Management of Environmental Quality: An International Journal. 31, 32, 2020.

14. KEHO Y. The impact of trade openness on economic growth: The case of Cote d'Ivoire. Cogent Economics \& Finance. 5 (1), 1332820, 2017.
15. HUCHET-BOURDON M., LE MOUËL C., VIJIL M The relationship between trade openness and economic growth: Some new insights on the openness measurement issue. World Economy. 41 (1), 59, 2018.

16. JAMEL L., MAKTOUF S. The nexus between economic growth, financial development, trade openness, and $\mathrm{CO}_{2}$ emissions in European countries. Cogent Economics \& Finance. 5 (1), 1341456, 2017.

17. KASMAN A., DUMAN Y.S. $\mathrm{CO}_{2}$ emissions, economic growth, energy consumption, trade and urbanisation in new EU member and candidate countries: a panel data analysis. Economic modelling. 44, 97, 2015.

18. RAFINDADI A.A. Does the need for economic growth influence energy consumption and $\mathrm{CO}_{2}$ emissions in Nigeria? Evidence from the innovation accounting test. Renewable and Sustainable Energy Reviews. 62, 1209, 2016.

19. WASTI S.K.A, ZAIDI S.W. An empirical investigation between $\mathrm{CO}_{2}$ emission, energy consumption, trade liberalisation and economic growth: A case of Kuwait. Journal of Building Engineering. 28, 101104, 2020.

20. ANTONAKAKIS N., CHATZIANTONIOU I., FILIS G. Energy consumption, $\mathrm{CO}_{2}$ emissions, and economic growth: An ethical dilemma. Renewable and Sustainable Energy Reviews. 68, 808, 2017.

21. KHAN M.K., KHAN M.I., REHAN M. The relationship between energy consumption, economic growth and carbon dioxide emissions in Pakistan. Financial Innovation. 6 (1), 1, 2020.

22. MENSAH I.A., SUN M., GAO C., OMARI-SASU A. Y., ZHU D., AMPIMAH B. C., QUARCOO A. Analysis on the nexus of economic growth, fossil fuel energy consumption, $\mathrm{CO}_{2}$ emissions and oil price in Africa based on a PMG panel ARDL approach. Journal of Cleaner Production. 228, 161, 2019.

23. BEGUM R.A., SOHAG K., ABDULLAH S.M.S., JAAFAR $\mathrm{M}$. $\mathrm{CO}_{2}$ emissions, energy consumption, economic and population growth in Malaysia. Renewable and Sustainable Energy Reviews. 41, 594, 2015.

24. BELAÏD F., ZRELLI M.H. Renewable and non-renewable electricity consumption, environmental degradation and economic development: Evidence from Mediterranean countries. Energy Policy. 133, 110929, 2019.

25. RAS - Razvojna agencija Srbije, Available at https://ras. gov.rs/ (accessed on 30 May 2020).

26. PAREŽANIN M., JEDNAK S., KRAGULJ D. The impact of FDI on the economic growth of Serbia. Management: Journal of Sustainable Business and Management Solutions in Emerging Economies. 21, 25, 2016.

27. JEDNAK S., KRAGULJ D., BULAJIC M., PITTMAN R. Electricity reform in Serbia. Utilities Policy. 17 (1), 125, 2009.

28. BOŽIĆ V.S, CVETKOVIĆ S.M., ŽIVKOVIĆ B.D. Influence of renewable energy sources on climate change mitigation in Serbia. Thermal Science, 19, 411, 2015.

29. GLOBAL CARBON ATLAS. Available at http://www. globalcarbonatlas.org/en/CO2-emissions (accessed on 30 May 2020).

30. WANG Y., WANG Y., ZHOU J., ZHU X., LU G. Energy consumption and economic growth in China: a multivariate causality test. Energy Policy. 39 (7), 4399, 2011.

31. SAINT AKADIRI S., ALOLA A.A., AKADIRI A.C., ALOLA U.V. Renewable energy consumption in EU-28 countries: Policy toward pollution mitigation and economic sustainability. Energy Policy. 132, 803, 2019. 
32. CHEN C., PINAR M., STENGOS T. Renewable energy consumption and economic growth nexus: Evidence from a threshold model. Energy Policy. 139, 111295, 2020.

33. ALI S., YING L., SHAH T., TARIQ A., ALI CHANDIO A., ALI I. Analysis of the Nexus of $\mathrm{CO}_{2}$ Emissions, Economic Growth, Land under Cereal Crops and Agriculture Value-Added in Pakistan Using an ARDL Approach. Energies. 12 (23), 4590, 2019.

34. PESARAN M.H., SHIN Y., SMITH R.J. Bounds testing approaches to the analysis of level relationships. Journal of applied econometrics. 16 (3), 289, 2001.

35. ZAMBRANO-MONSERRATE M.A., SILVAZAMBRANO C.A., DAVALOS-PENAFIEL J.L., ZAMBRANO-MONSERRATE A., RUANO M.A. Testing environmental Kuznets curve hypothesis in Peru: The role of renewable electricity, petroleum and dry natural gas. Renewable and Sustainable Energy Reviews. 82, 4170, 2018.

36. SHAHBAZ M., JAM F.A., BIBI S., LOGANATHAN N. Multivariate Granger causality between $\mathrm{CO}_{2}$ emissions, energy intensity and economic growth in Portugal: evidence from co integration and causality analysis. Technological and Economic Development of Economy. 22 (1), 47, 2016.

37. NEPAL R., PAIJA N. Energy security, electricity, population and economic growth: The case of a developing South Asian resource-rich economy. Energy Policy. 132, 771, 2019.

38. NARAYAN P.K., SMYTH R. Electricity consumption, employment and real income in Australia: Evidence from multivariate Granger causality tests. Energy policy. 33 (9), 1109, 2005.

39. SINHA A., SHAHBAZ M. Estimation of environmental Kuznets curve for $\mathrm{CO}_{2}$ emission: role of renewable energy generation in India. Renewable Energy. 119, 703, 2018.

40. NARAYAN P.K. The saving and investment nexus for China: evidence from co integration tests. Applied economics. 37 (17), 1979, 2005.

41. WANG S., LI Q., FANG C., ZHOU C. The relationship between economic growth, energy consumption, and $\mathrm{CO}_{2}$ emissions: Empirical evidence from China. Science of the Total Environment. 542, 360, 2016.

42. GRANGER C.W. Investigating causal relations by econometric models and cross-spectral methods. Econometrica: Journal of the Econometric Society. 37, 424, 1969.

43. SHRESTHA M.B., BHATTA G.R. Selecting appropriate methodological framework for time series data analysis. The Journal of Finance and Data Science. 4 (2), 71, 2018.

44. ELYAS R., MASIH M. Does environmental awareness determine GDP growth? Evidence from Singapore based on ARDL and NARDL approaches. 2019. Available at https://mpra.ub.uni-muenchen.de/94683/1/MPRA paper_94683.pdf (accessed on 30 May 2020).

45. AKAIKE H.A. New look at the statistical model identification. IEEE transactions on automatic control. 19 (6), 716, 1974.

46. SCHWARZ G. Estimating the dimension of a model. Annals Statistics. 6, 461, 1978.

47. BROWN R.L., DURBIN J., EVANS J.M. Techniques for testing the constancy of regression relationships over time. Journal of the Royal Statistical Society: Series B (Methodological). 37 (2), 149, 1975.

48. BILAN Y., STREIMIKIENE D., VASYLIEVA T., LYULYOV O., PIMONENKO T., PAVLYK A. Linking between renewable energy, $\mathrm{CO}_{2}$ emissions, and economic growth: challenges for candidates and potential candidates for the EU membership. Sustainability. 11, 1528, 2019.

49. KASPEROWICZ R. Economic growth and $\mathrm{CO}_{2}$ emissions: The ECM analysis. Journal of International Studies. 8 (3), 91, 2015.

50. SUN C., ZHANG F., XU M. Investigation of pollution haven hypothesis for China: an ARDL approach with breakpoint unit root tests. Journal of cleaner production. 161, 153, 2017.

51. HOSSAIN M.S. Panel estimation for $\mathrm{CO}_{2}$ emissions, energy consumption, economic growth, trade openness and urbanisation of newly industrialised countries. Energy Policy. 39 (11), 6991, 2011.

52. HOSSAIN S. An econometric analysis for $\mathrm{CO}_{2}$ emissions, energy consumption, economic growth, foreign trade and urbanisation of Japan. Low Carbon Economy. 3, 92, 2012.

53. BEHERA S.R., DASH D.P. The effect of urbanisation, energy consumption, and foreign direct investment on the carbon dioxide emission in the SSEA (South and Southeast Asian) region. Renewable and Sustainable Energy Reviews. 70, 96, 2017.

54. HOFFMANN R, LEE C.G., RAMASAMY B., YEUNG M. FDI and pollution: a Granger causality test using panel data. Journal of International Development: The Journal of the Development Studies Association. 17 (3), 311, 2005.

55. ZAKARYA G.Y., MOSTEFA B., ABBES S.M., SEGHIR G.M. Factors affecting $\mathrm{CO}_{2}$ emissions in the BRICS countries: a panel data analysis. Procedia Economics and Finance. 26, 114, 2015.

56. AL-MULALI U, TANG C.F. Investigating the validity of pollution haven hypothesis in the gulf cooperation council (GCC) countries. Energy Policy. 60, 813, 2013.

57. DEMENA B.A., AFESORGBOR S.K. The effect of FDI on environmental emissions: Evidence from a metaanalysis. Energy Policy. 138, 111192, 2020.

58. APERGIS N, TANG C.F. Is the energy-led growth hypothesis valid? New evidence from a sample of 85 countries. Energy Economics. 38, 24, 2013.

59. KAHIA M., AÏSSA M.B., LANOUAR C. Renewable and non-renewable energy use-economic growth nexus: The case of MENA Net Oil Importing Countries. Renewable and Sustainable Energy Reviews. 71,127, 2017.

60. MENEGAKI A.N. Growth and renewable energy in Europe: a random effect model with evidence for neutrality hypothesis. Energy Economics. 33 (2), 257, 2011.

61. AHMED K., REHMAN M.U., OZTURK I. What drives carbon dioxide emissions in the long-run? Evidence from selected South Asian countries. Renewable and Sustainable Energy Reviews. 70, 1142, 2017.

62. SANNASSEE R.V., SEETANAH B. Trade openness and $\mathrm{CO}_{2}$ emission: evidence from a SIDS. In Handbook of environmental and sustainable finance Academic Press. 165, 2016.

63. MUTASCU M. A time-frequency analysis of trade openness and $\mathrm{CO}_{2}$ emissions in France. Energy policy. 115, 443, 2018

64. TIBA S., FRIKHA M. Income, trade openness and energy interactions: Evidence from simultaneous equation modelling. Energy. 147, 799, 2018.

65. ACARAVCI A., OZTURK I. Electricity consumptiongrowth nexus: evidence from panel data for transition countries. Energy Economics. 32 (3), 604, 2010. 